\title{
CONTRASTING HABITAT ASSOCIATIONS OF SAGEBRUSH-STEPPE SONGBIRDS IN THE INTERMOUNTAIN WEST
}

ROBERT A. MILLER, Intermountain Bird Observatory, 1910 University Drive, MS1515, Boise, Idaho 83725; RobertMiller7@boisestate.edu

LAURA BOND, Biomolecular Research Center, 1910 University Drive, MS1515, Boise, Idaho 83725

PATRICK N. MIGAS, JAY D. CARLISLE, and GREGORY S. KALTENECKER, Intermountain Bird Observatory, 1910 University Drive, MS1515, Boise, Idaho 83725

ABSTRACT: Sagebrush (Artemisia spp.) steppe is one of North America's most imperiled ecosystems, as the result of many factors including grazing, development, fire, and invasion of exotic plants. Threats to sagebrush steppe are expected to increase because of climate change and further human development. Many songbirds use sagebrush steppe opportunistically, but a few obligate species are dependent on it. To quantify the habitat associations of three sagebrush obligates, the Sage Thrasher (Oreoscoptes montanus), Sagebrush Sparrow (Artemisiospiza nevadensis), and Brewer's Sparrow (Spizella breweri), and nine other songbird species that use this habitat, we surveyed across a broad region of Idaho. At each of 104 sites, we selected three plots, one each in relatively poor, moderate, and good condition, defined qualitatively by the cover of native shrubs. We quantified bird abundance by point counts, described the habitat at these points by a line-intercept method, and at each plot calculated the fraction of a circle (radius $1 \mathrm{~km}$ ) covered in shrubs or grassland. We compared two-scale occupancy models based on these data by the information-theoretic approach. According to the models, our qualitative assessment of habitat condition within a site distinguished birds' use of relatively good habitat from their use of poor habitats only, not from those in moderate condition. Thus the sagebrush-obligate species may tolerate some local habitat degradation, at least up to some unidentified threshold. Occurrence of all three sagebrush obligates correlated well with one or more characteristics of sagebrush such as its cover, height, or heterogeneity in height. They differed in the Sage Thrasher being most sensitive to sagebrush cover, the Sagebrush Sparrow being found more often at lower elevations, and the Brewer's Sparrow being less sensitive to ground cover. The nine other species evaluated were less or negatively associated with attributes of sagebrush. On the basis of these results, we suggest that the three sagebrush obligates are best conserved by promoting shrublands over a broad range of elevations, containing both sagebrush and other shrubs in patches of mixed height, and minimizing invasive annual grasses.

Sagebrush steppe, growing in semiarid climates with substantial variation in annual rainfall, is dominated by both sagebrush (Artemisia spp.) and herbaceous plants. In western North America it has been degraded by many forces including agriculture, improper livestock grazing, energy development, urbanization, invasive species, and fire (Connelly et al. 2004, Hanser and Knick 2011). West (2000) estimated that over 60\% of pre-Columbian sagebrush steppe has been invaded by exotic plants, changing its structure. The result is that sagebrush steppe is now one of North America's most imperiled ecosystems (Dobkin and Sauder 2004, Chambers and Wisdom 2009). It continues to be threatened by altered fire regimes resulting from invasions of exotic grasses (Brooks et al. 2004, Holmes and Robinson 2013), which accelerate the effects of other anthropogenic factors (Leu et 
al. 2008) and may compound the effects of climate change (Bradley 2010, Schlaepfer et al. 2012). Over 100 species of birds either forage or nest in sagebrush steppe, some of which are threatened by the habitat degradation (Baker et al. 1976).

The songbirds using sagebrush steppe can be classified as (1) sagebrush obligates, species almost entirely dependent on this habitat, (2) near obligates, which spend much of their life in sagebrush steppe but also exist elsewhere, generally in lower numbers, and (3) sagebrush-associated birds, which are often common in sagebrush steppe but occur regularly in other habitats as well (Baker et al. 1976). Dobkin and Sauder (2004) reported that of 12 common sagebrush obligates, near obligates, and associated bird species, half have suffered long-term declines across the West (1968-2001), three more have declined within the Columbia Plateau ecoregion, and only one, the Gray Flycatcher (Empidonax wrightii), has enjoyed a long-term increase. Of the three sagebrush obligates, the Brewer's Sparrow (Spizella breweri) has shown a long-term decline throughout the West, the Sagebrush Sparrow (Artemisiospiza nevadensis) has shown a mixed trend throughout the West (declining between 1968 and 1983, yet increasing in the Great Basin ecoregion between 1984 and 2001), and the Sage Thrasher (Oreoscoptes montanus) has shown a decline within the Columbia Plateau ecoregion. The single near obligate, the Vesper Sparrow (Pooecetes gramineus), has shown no downward trend (Dobkin and Sauder 2004).

The early studies of the habitat associations of the songbirds of sagebrush steppe focused on a single or few species (e.g., Reynolds 1981, Petersen and Best 1985), analyzed few habitat variables (e.g., Petersen and Best 1985), or were limited geographically (e.g., Petersen and Best 1985, Knick and Rotenberry 1995, Vander Haegen et al. 2000). More recent studies have had a wider geographic scope and have addressed a broader set of species (e.g., Hanser and Knick 2011). However, more large-scale studies of a diverse set of focal species are needed to inform conservation and restoration on a large scale (Knick et al. 2008, Meinke et al. 2009).

In prioritizing management for conservation of species, biologists often assess habitat quality subjectively, particularly when time or other resources are limited. In many cases, these designations are intended for one species, such as the Greater Sage-Grouse (Centrocercus urophasianus), but are expected to be correlated with the needs of other species such as sagebrush-obligate songbirds (Hanser and Knick 2011). In some habitats, subjective rankings can be accurate, especially if the assessors receive regular training (Wilson et al. 2007). Although the bias of these rankings is not always greater than that of a quantitative model, McCarthy et al. (2004) showed subjective measures to be more biased in particular directions such as overestimating the difference between two classes. Therefore, the scale and direction of bias should be measured and evaluated before key decisions are made on the basis of subjective quality assessments (McCarthy et al. 2004).

Our study had two objectives. First, to identify habitat associations for 12 species of sagebrush-obligate, near-obligate, and sagebrush-associated songbirds across the sagebrush steppe of Idaho by a consistent method. Second, to evaluate the applicability of field biologists' subjective ranking of habitat quality for management of sage-grouse to sagebrush-obligate 
songbirds. Our goal is that our results inform management and conservation plans so that these songbirds can be conserved more effectively as their habitat continues to change.

\section{METHODS}

\section{Study Area}

We surveyed sagebrush-steppe songbirds and habitat throughout southern and central Idaho (42.0-45.2 $2^{\circ} \mathrm{N}, 111.5-117.0^{\circ} \mathrm{W}$; Figure 1) during the breeding seasons of 2002, 2003, 2004, and 2006. The study area encompassed approximately 16 million hectares, owned variously by the $U$. S. Bureau of Land Management, U.S. Forest Service, U. S. National Park Service (Craters of the Moon National Monument), U. S. Department of Defense (Idaho National Laboratory), state of Idaho, and private landowners.

\section{Site Selection}

We organized surveys hierarchically into sites, each encompassing three plots, each of which encompassed eight points (Figure 2). We chose sites by consulting biologists with various agencies to identify areas of high-quality sagebrush steppe. We sampled a total of 104 sites ranging in size from 300 to 8497 ha and in elevation from 913 to $2323 \mathrm{~m}$. In most cases, we

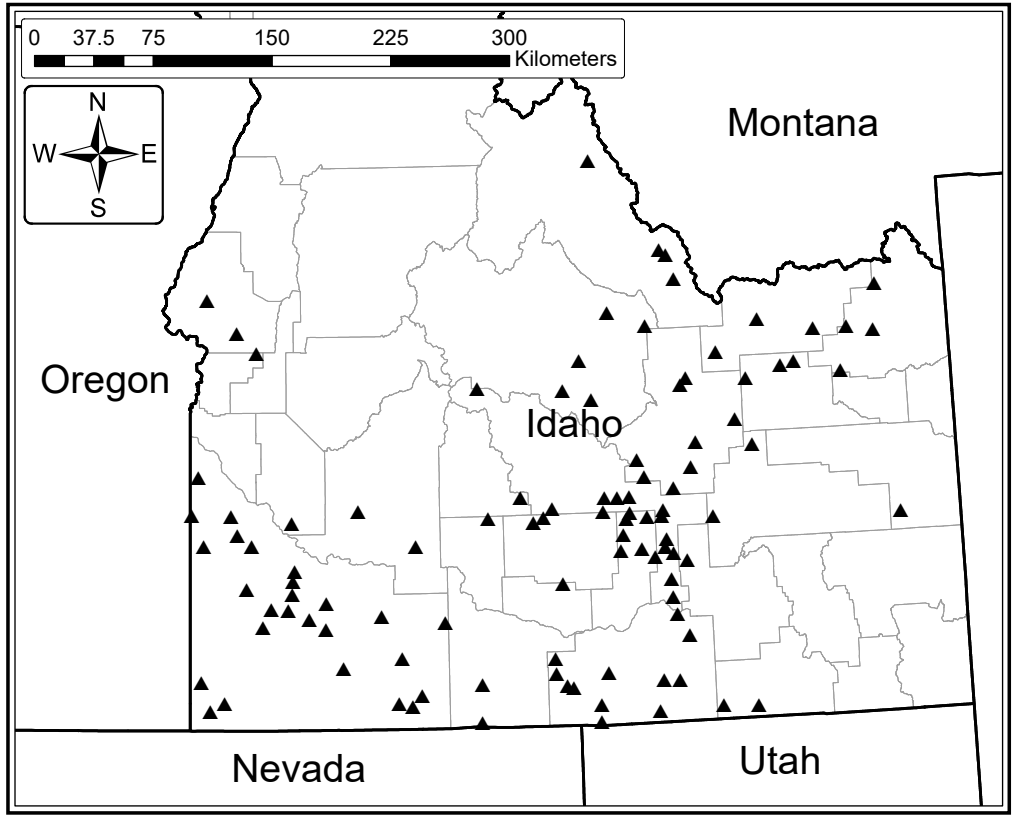

Figure 1. Sites $(n=104)$ surveyed for songbirds in sagebrush steppe across southern and central Idaho in 2002, 2003, 2004, and 2006. 


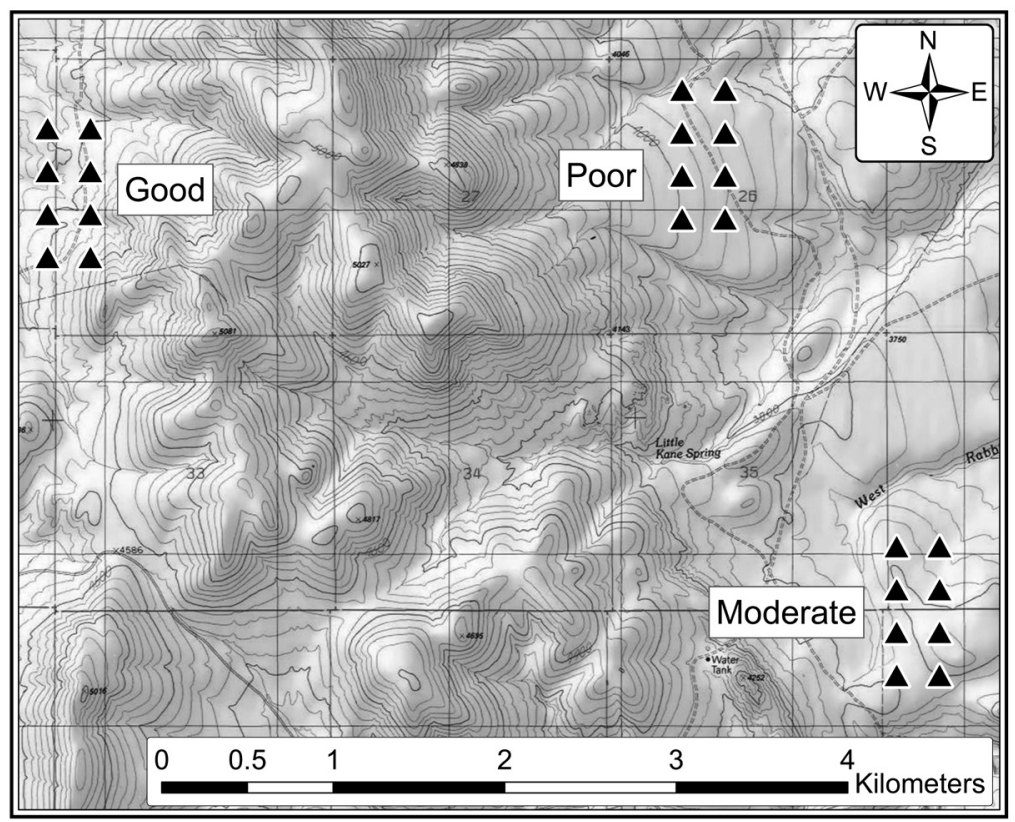

Figure 2. Example study site (Mountain Home-2) in southwest Idaho, showing three plots of varying habitat quality, each with eight survey points separated by $250 \mathrm{~m}$ in a four-by-two grid.

located sites within Greater Sage-Grouse habitat or areas thought suitable for restoration of sage-grouse habitat. We then searched for nearby areas of lower-quality habitat to provide a contrast within the site, the primary factor influencing the size of each site. Within each site, we established three plots, one each in relatively good, moderate, and poor habitats, defined primarily by cover of native shrubs. Approximately 100 ha of contiguous habitat in similar condition were required for establishment of each plot. Within each site, we chose plots similar in elevation, slope, aspect, and soil type, under the assumption that all plots within a site had the same potential for both vegetation and birds but that past disturbances such as fire, grazing, recreation had created variation in habitat quality. We made no attempt to standardize relative quality from site to site (i.e., a "poor" plot at one site could conceivably be better than a "good" plot at another site).

Within each plot, we defined eight points $250 \mathrm{~m}$ apart, usually in four rows and two columns oriented north to south, but we occasionally modified this arrangement to accommodate local geography (Figure 2). The distance between plots ranged from $250 \mathrm{~m}$ to $17 \mathrm{~km}$.

\section{Songbird and Habitat Surveys}

At each point, we followed a modified version of the bird-survey protocol of the Point Reyes Bird Observatory's Shrub-steppe Bird Project (Point Reyes 
Bird Observatory 2001), counting all birds within $200 \mathrm{~m}$ for 5 minutes. Surveys extended from 30 minutes before to 5 hours after local sunrise (Hanser and Knick 2011, Hanni et al. 2013). Over the four years of the study, we surveyed each point only once, between 28 April and 2 July. Within a year, we surveyed at lower elevations earlier in the season and progressed to higher elevations later in the season.

We approached each survey point quietly to minimize disturbance to birds and waited at least 2 minutes before beginning the count. If birds flushed from the area upon our arrival and did not return for the duration of the count, we did not include them in our results. Except for birds using the habitat in flight, such as a Horned Lark (Eremophila alpestris) in display flight, we excluded birds flying over the plot. We estimated the distance to each bird by increments of $25 \mathrm{~m}$ out to $100 \mathrm{~m}$ or as between 100 and $200 \mathrm{~m}$. We later truncated the data to $100 \mathrm{~m}$. We did not count during heavy rains or when winds exceeded $20 \mathrm{~km} / \mathrm{hr}$.

We assessed habitat by the line-point-intercept method, selecting this technique because of its widespread use with rangeland and shrubland in southern Idaho (U.S. Department of the Interior 2000). The habitat surveys were typically completed within two days of the bird counts.

At each point, we established a 100-m vegetation transect from north to south, centering it at the point. Along each transect, we recorded vegetation every $2 \mathrm{~m}$, for a total of 50 measurements per transect. Starting at 0 $\mathrm{m}$, we dropped a calibrated measuring rod vertically at arm's length, then recorded each species of plant touching the rod by one, two, or three layers of vegetation. Thus a maximum of 150 vegetation "hits" was possible per transect. We recorded the maximum height (in $\mathrm{cm}$ ), including the height of seed heads, of each plant touching the measuring rod. We also recorded the substrate at each point of vegetation sampling, including bare ground, rock, litter, or biological soil crust.

\section{Statistical Analyses}

Data summary. For each bird-survey point we recorded or calculated 18 habitat variables (Table 1). These included the mean heights of annual and perennial forbs, annual and perennial grasses, sagebrush, other shrubs, and total shrubs (sagebrush and others pooled), averaged from the 50 vegetationsampling points associated with that bird-count point. For an index of the variation in shrub heights (heterogeneity of height), we calculated the standard deviation of heights of sagebrush and of all shrubs combined for each point (McElhinny et al. 2005). To calculate the percent cover of each of these seven categories of vegetation, we divided the number of times each vegetation type was recorded for a point (number of "hits") by the total number of hits possible for a point (150). We defined the combined categories of bare soil, rock, and biological soil crust as "bare ground," and calculated its percent (of 50 possible) along each transect. With litter defined as any dead organic matter that covered the soil surface, we calculated its percent in similar fashion.

We quantified the habitat at the scale of the plot by calculating the mean elevation within $1 \mathrm{~km}$ of the center of each plot and the proportion of this 
Table 1 Quantification of Habitat at 2481 Points Surveyed for Songbird-Habitat Relationships in Shrub-Steppe of Southern and Central Idaho, April-July, 20022006, by Three Subjective Rankings of Habitat Quality

\begin{tabular}{|c|c|c|c|c|c|}
\hline \multirow[b]{2}{*}{ Habitat variable $^{a}$} & \multicolumn{2}{|c|}{ All points pooled } & \multicolumn{3}{|c|}{ By category of habitat quality } \\
\hline & Mean \pm SE & Range & Good & Moderate & Poor \\
\hline $\begin{array}{l}\text { Cover of annual } \\
\text { forbs (\%) }\end{array}$ & $2.0 \pm 0.1$ & $0.0-26.7$ & $2.1 \pm 0.1$ & $1.8 \pm 0.1$ & $2.1 \pm 0.1$ \\
\hline Mean height of annual forbs (cm) & $10.2 \pm 0.3$ & $2.5-128.3$ & $10.4 \pm 0.5$ & $10.3 \pm 0.4$ & $9.9 \pm 0.4$ \\
\hline Cover of perennial forbs (\%) & $3.0 \pm 0.1$ & $0.0-22.0$ & $3.2 \pm 0.1$ & $3.0 \pm 0.1$ & $2.7 \pm 0.1$ \\
\hline $\begin{array}{l}\text { Mean height of perennial } \\
\text { forbs }(\mathrm{cm})\end{array}$ & $13.8 \pm 0.2$ & $2.5-63.5$ & $14.3 \pm 0.4$ & $13.8 \pm 0.3$ & $13.2 \pm 0.4$ \\
\hline Cover of annual grass (\%) & $3.2 \pm 0.1$ & $0.0-32.7$ & $3.2 \pm 0.2$ & $3.0 \pm 0.2$ & $3.3 \pm 0.2$ \\
\hline Mean height of annual grass (cm) & $13.9 \pm 0.2$ & $2.5-76.2$ & $14.4 \pm 0.4$ & $13.4 \pm 0.3$ & $13.9 \pm 0.3$ \\
\hline Cover of perennial grass (\%) & $10.0 \pm 0.1$ & $0.0-29.3$ & $9.9 \pm 0.2$ & $9.8 \pm 0.2$ & $10.3 \pm 0.2$ \\
\hline $\begin{array}{l}\text { Mean height of perennial } \\
\text { grass }(\mathrm{cm})\end{array}$ & $19.4 \pm 0.2$ & $2.5-71.8$ & $19.0 \pm 0.4$ & $18.8 \pm 0.3$ & $20.5 \pm 0.4$ \\
\hline Cover of sagebrush (\%) & $6.3 \pm 0.1$ & $0.0-22.0$ & $8.3 \pm 0.1$ & $6.6 \pm 0.2$ & $4.0 \pm 0.1$ \\
\hline Mean height of sagebrush $(\mathrm{cm})$ & $59.0 \pm 0.5$ & $5.1-205.7$ & $64.7 \pm 0.8$ & $58.1 \pm 0.8$ & $53.2 \pm 0.9$ \\
\hline SD of sagebrush height $(\mathrm{cm})$ & $20.6 \pm 0.3$ & $0.0-118.1$ & $23.5 \pm 0.4$ & $21.1 \pm 0.4$ & $16.3 \pm 0.5$ \\
\hline $\begin{array}{l}\text { Cover of shrubs other than } \\
\text { sagebrush (\%) }\end{array}$ & $2.2 \pm 0.1$ & $0.0-25.3$ & $2.4 \pm 0.1$ & $2.2 \pm 0.1$ & $2.1 \pm 0.1$ \\
\hline $\begin{array}{l}\text { Mean height of shrubs other than } \\
\text { sagebrush }(\mathrm{cm})\end{array}$ & $46.9 \pm 0.9$ & $2.5-564.5$ & $50.8 \pm 1.2$ & $45.2 \pm 1.5$ & $44.5 \pm 1.7$ \\
\hline Cover of all shrubs pooled (\%) & $8.5 \pm 0.1$ & $0.0-34.7$ & $10.6 \pm 0.2$ & $8.9 \pm 0.2$ & $6.1 \pm 0.2$ \\
\hline $\begin{array}{l}\text { Mean height of all shrubs } \\
\text { pooled }(\mathrm{cm})\end{array}$ & $55.5 \pm 0.5$ & $2.5-355.6$ & $61.4 \pm 0.7$ & $54.9 \pm 0.7$ & $49.5 \pm 1.0$ \\
\hline SD of height of all shrubs $(\mathrm{cm})$ & $22.9 \pm 0.4$ & $0.0-335.6$ & $25.3 \pm 0.5$ & $23.1 \pm 0.5$ & $20.1 \pm 0.8$ \\
\hline Cover of bare ground (\%) & $33.5 \pm 0.3$ & $0.0-86.0$ & $32.2 \pm 0.6$ & $34.0 \pm 0.5$ & $34.2 \pm 0.6$ \\
\hline Cover of litter (\%) & $11.5 \pm 0.2$ & $0.0-78.0$ & $11.8 \pm 0.4$ & $11.2 \pm 0.4$ & $11.4 \pm 0.4$ \\
\hline
\end{tabular}

a Summary statistics for height variables based only on points where percent cover for that variable was greater than zero.

circle in each of the primary habitats defined in the 2005 Shrubmap dataset (Hanser et al. 2005, Hanser and Knick 2011). We combined related categories to create three plot-scale habitat variables: mean elevation, proportion of circle with shrubs as primary habitat, and the proportion of circle with grassland as primary habitat (Table 2).

We defined each species of bird as present if we detected it within $100 \mathrm{~m}$ of a point. For analysis, we selected 12 species more or less associated with sagebrush steppe (Table 3). To aid comparison of the results, we grouped species by the categories of habitat use suggested by Baker et al. (1976) and Paige and Ritter (1999; Table 3).

Habitat-quality designations. For each of the 12 species, to assess the differences in its occurrence by the three subjective levels of habitat quality used to define the plots within the sites, we evaluated its mean probability of plot occupancy $(\Psi)$ for each of the three levels while holding all habitat variables at their mean values from all plots within each level. To aid in interpretation, we generated and report 95\% confidence intervals on $\Psi$, considering a difference to be significant if the 95\% confidence interval of the estimate for one level did not overlap the estimate of another level. 
Table 2 Quantification of Habitat within a 1-km Radius Centered in 312 Plots Surveyed for Songbird-Habitat Relationships in Shrub-Steppe of Southern and Central Idaho, April-July, 2002-2006, by Three Subjective Rankings of Habitat Quality

\begin{tabular}{lcccccc}
\hline & \multicolumn{2}{c}{ All points pooled } & & \multicolumn{3}{c}{ By category of habitat quality } \\
\cline { 2 - 3 } \cline { 6 - 7 } Habitat variable & Mean \pm SE & Range & & Good & Moderate & Poor \\
\hline Mean elevation $(\mathrm{m})$ & $1551.6 \pm 5.6$ & $912.8-2323.2$ & & $1553.7 \pm 2.7$ & $1553.2 \pm 2.7$ & $1546.5 \pm 2.7$ \\
Proportion shrubs $^{a}$ & $0.75 \pm 0.02$ & $0.00-1.00$ & & $0.82 \pm 0.02$ & $0.78 \pm 0.03$ & $0.72 \pm 0.03$ \\
Proportion grassland $^{a}$ & $0.11 \pm 0.01$ & $0.00-0.97$ & & $0.06 \pm 0.01$ & $0.12 \pm 0.02$ & $0.16 \pm 0.03$ \\
\hline
\end{tabular}

${ }^{a}$ Values derived from Shrubmap (Hanser et al. 2005).

Bird-habitat relationships. To assess birds' habitat relationships, we used hierarchical multi-scale occupancy modeling for each of the 12 species (Table 3; Nichols et al. 2008, Pavlacky et al. 2012). This approach allows for "the simultaneous use of presence-absence data at two spatial scales, accounts for non-independence of detections between scales, addresses the closure assumption for spatially replicated survey stations, and estimates occupancy at both small and large scales" (Pavlacky et al. 2012). The models may include separate or repeated covariates for the probability of detection at a point, given that the point is occupied $(p)$, the probability of the point being occupied, given that the plot is occupied $(\Theta)$, and the probability that the plot is occupied ( $\Psi$; Pavlacky et al. 2012).

We did not consistently record observations by interval within each 5-minute count, nor did we repeat samples. Therefore, we are unable to evaluate covariates for, or calculate, the probability of a species' being detected. At the point scale, we centered each of the 18 habitat variables, by subtracting the mean of the values from each value (i.e., shifting the range of values so the mean is centered on zero). We then scaled the habitat variables by dividing the centered values by the standard deviation. We used the centered and scaled results to generate principal components and used varimax rotation to improve interpretability (McCune and Grace 2002). We chose relevant components on the basis of eigenvalues $(>1)$ and scree plot "elbow-test" examination (Abdi and Williams 2010).

Next, we devised a set of candidate models that might describe our data, based in part on the top five principal components calculated from the 18 point-scale habitat variables influencing the probability of a species being present at a point, given the plot is occupied $(\Theta$, Table 4), as well as the squares of these values. Also contributing to the set were the three plot-scale variables (measured within the 1-km radius) influencing the probability of the plot being occupied ( $\Psi$; Table 2 ), as well as the squares of these values. The set of models did not contain any covariates for the probability of detection (p). We ranked the full set of models by Akaike's information criterion adjusted for small sample sizes ( $\mathrm{AIC}_{c}$; Burnham and Anderson 2002). We report all models falling within two $\mathrm{AIC}_{c}$ units of the top model (supplemental tables S1-S12 at www.westernfieldornithologists.org/48-1_tables.pdf) but used only the top-ranked model for evaluating an effect (Arnold 2010). We generated predicted effect sizes for each variable in the top model for each species of bird by ranging the variable of interest across its sampled range while holding all other variables at their mean values from all plots. 
Table 3 Habitat Guilds and Number of Points of Detection of Principal Songbirds Surveyed for Habitat Relationships in Shrub-Steppe of Southern and Central Idaho, April-July, 2002-2006

\begin{tabular}{|c|c|c|c|}
\hline Species & Code & Habitat guild ${ }^{a}$ & $\begin{array}{l}\text { Number of points } \\
\text { of detection }\end{array}$ \\
\hline $\begin{array}{l}\text { Sage Thrasher (Oreoscoptes } \\
\text { montanus) }\end{array}$ & SATH & Sagebrush obligate & 607 \\
\hline Brewer's Sparrow (Spizella breweri) & BRSP & Sagebrush obligate & 1592 \\
\hline $\begin{array}{l}\text { Sagebrush Sparrow (Artemisiospiza } \\
\text { nevadensis) }\end{array}$ & SAGS & Sagebrush obligate & 347 \\
\hline $\begin{array}{l}\text { vesper sparrow (Pooecetes } \\
\text { gramineus) }\end{array}$ & VESP & Sagebrush near obligate & 794 \\
\hline $\begin{array}{l}\text { wrightii) } \\
\text { Green-tailed Towhee (Pipilo }\end{array}$ & GRFL & Sagebrush-woodland & 95 \\
\hline $\begin{array}{l}\text { chlorurus) } \\
\text { Loggerhead Shrike (Lanius }\end{array}$ & GTTO & Sagebrush-woodland & 80 \\
\hline $\begin{array}{l}\text { ludovicianus) } \\
\text { Lark Sparrow (Chondestes }\end{array}$ & $\mathrm{LOSH}$ & Shrubland & 55 \\
\hline grammacus) & LASP & Habitat generalist & 231 \\
\hline Horned Lark (Eremophila alpestris) & HOLA & Open/disturbed habitat & 1174 \\
\hline $\begin{array}{l}\text { Savannah Sparrow (Passerculus } \\
\text { sandwichensis) }\end{array}$ & SAVS & Open/disturbed habitat & 26 \\
\hline $\begin{array}{l}\text { Western Meadowlark (Sturnella } \\
\text { neglecta) } \\
\text { Grasshopper Sparrow }\end{array}$ & WEME & Open/disturbed habitat & 1165 \\
\hline (Ammodramus savannarum) & GRSP & Grassland & 128 \\
\hline
\end{tabular}

${ }^{a}$ As defined by Baker et al. (1976) and Paige and Ritter (1999).

${ }^{b}$ Of 2481 points total.

For the core statistical analyses we used the programs $\mathrm{R}$ and Mark (White and Burnham 1999, R Development Core Team 2013). We used Mark for the multi-scale occupancy modeling and $\mathrm{R}$ for data structuring, descriptive statistics, principal component analysis, graphing, and interfacing with Mark ( $\mathrm{R}$ package "RMark" for the latter; Laake 2014). We report means \pm standard errors in the results.

\section{RESULTS}

Including all detections, we counted a total of 18,366 birds of 95 species at 2481 points within the 104 study sites. The ten most abundant species were the Brewer's Sparrow $(n=4414)$, Horned Lark $(n=3845)$, Western Meadowlark $(n=3259)$, Vesper Sparrow $(n=1596)$, Sage Thrasher $(n=$ 1377), Sagebrush Sparrow ( $n=657)$, Lark Sparrow $(n=422)$, Mourning Dove (Zenaida macroura; $n=267$ ), Brown-headed Cowbird (Molothrus ater; $n=207)$, and Grasshopper Sparrow $(n=174)$.

\section{Habitat-Quality Designations}

The qualitative habitat designations made by field biologists were generally supported by our formal vegetative measurements (Tables 1, 2). Our results 
Table 4 Principal Component Loadings ${ }^{a}$ of 18 Habitat Variables Measured at 2481 Points within 312 Plots at 104 Sites Surveyed for Habitat Relationships in Shrub-Steppe of Southern and Central Idaho, April-July, 2002-2006

\begin{tabular}{lrrrrr}
\hline & \multicolumn{5}{c}{ Principal component axis $^{b}$} \\
\cline { 2 - 6 } Habitat variable & $1^{c}$ & $2^{d}$ & $3^{e}$ & $4^{f}$ & $5^{g}$ \\
\hline Cover of annual forbs & 11 & 50 & 14 & -15 & 1 \\
Mean height of annual forbs & -6 & 59 & 13 & 5 & 13 \\
Cover of annual grass & 10 & 77 & -23 & -10 & -17 \\
Mean height of annual grass & 9 & 73 & 1 & -3 & 8 \\
Cover of perennial forbs & 0 & 1 & 71 & 18 & 2 \\
Mean height of perennial forbs & 5 & 23 & 57 & 12 & 20 \\
Cover of perennial grass & 13 & -19 & 77 & -22 & 2 \\
Mean height of perennial grass & -9 & 18 & 33 & -12 & 41 \\
Cover of sagebrush & 15 & -16 & 3 & 89 & -15 \\
Mean height of sagebrush & 72 & 15 & 7 & 35 & -11 \\
SD of height of sagebrush & 64 & 8 & 3 & 46 & -15 \\
Cover of shrubs other than sagebrush & 10 & 5 & 2 & 15 & 87 \\
Mean height of shrubs other than sagebrush & 59 & -2 & 4 & -19 & 57 \\
Cover of all shrubs pooled & 19 & -10 & 4 & 86 & 40 \\
Mean height of all shrubs pooled & 89 & 11 & 9 & 7 & 5 \\
SD of height of all shrubs pooled & 85 & 2 & 4 & -2 & 19 \\
Cover of bare ground & -14 & -49 & -58 & -6 & -19 \\
Cover of litter & -2 & -1 & -36 & 4 & 26 \\
Cumulative \% of variance explained & 24 & 33 & 60 & 70 & 79 \\
Eigenvalue & 3.79 & 2.46 & 1.89 & 1.48 & 1.38 \\
\hline
\end{tabular}

${ }^{a}$ After centering, scaling and varimax rotation, multiplied by 100 and rounded to nearest integer. ${ }^{b}$ Shading highlights strong positive associations (absolute value of loading $\geq 0.5$ ).

${ }^{c}$ Represents a gradient of increasing height of shrubs (all species pooled) and increasing variability in this height.

${ }^{d}$ Represents a gradient of increasing height and cover of invasive annual grasses.

eRepresents a gradient of increasing cover of perennial grasses and forbs (of which $>90 \%$ were native species) and decreasing bare ground.

${ }^{f}$ Represents a gradient of increasing cover of sagebrush and all shrubs pooled.

${ }^{s}$ Represents a gradient of increasing cover of shrubs other than sagebrush.

confirm that the observers evaluating habitat quality used as criteria percent sagebrush cover, sagebrush height, heterogeneity of sagebrush height, and height and heterogeneity of total shrubs at the point scale (Table 1), as well as proportion of shrubs and grassland at the plot scale (Table 2). In all other habitat variables the three levels of quality overlapped considerably (Tables $1,2)$. In evaluating the subjective designations of habitat quality, we found the good and poor plots as defined by use by sage-grouse differed in rates of occupancy by the 12 species we assessed. For example, the 95\% confidence intervals of estimated occupancy of the good and poor plots did not overlap for six of the 12 species, including all three sagebrush obligates (Figure 3). In four cases the probability of occupancy of plots rated good and moderate differed by the criterion of 95\% confidence intervals-the Sagebrush Sparrow, Loggerhead Shrike, Horned Lark, and Grasshopper Sparrow (Figure 3). 


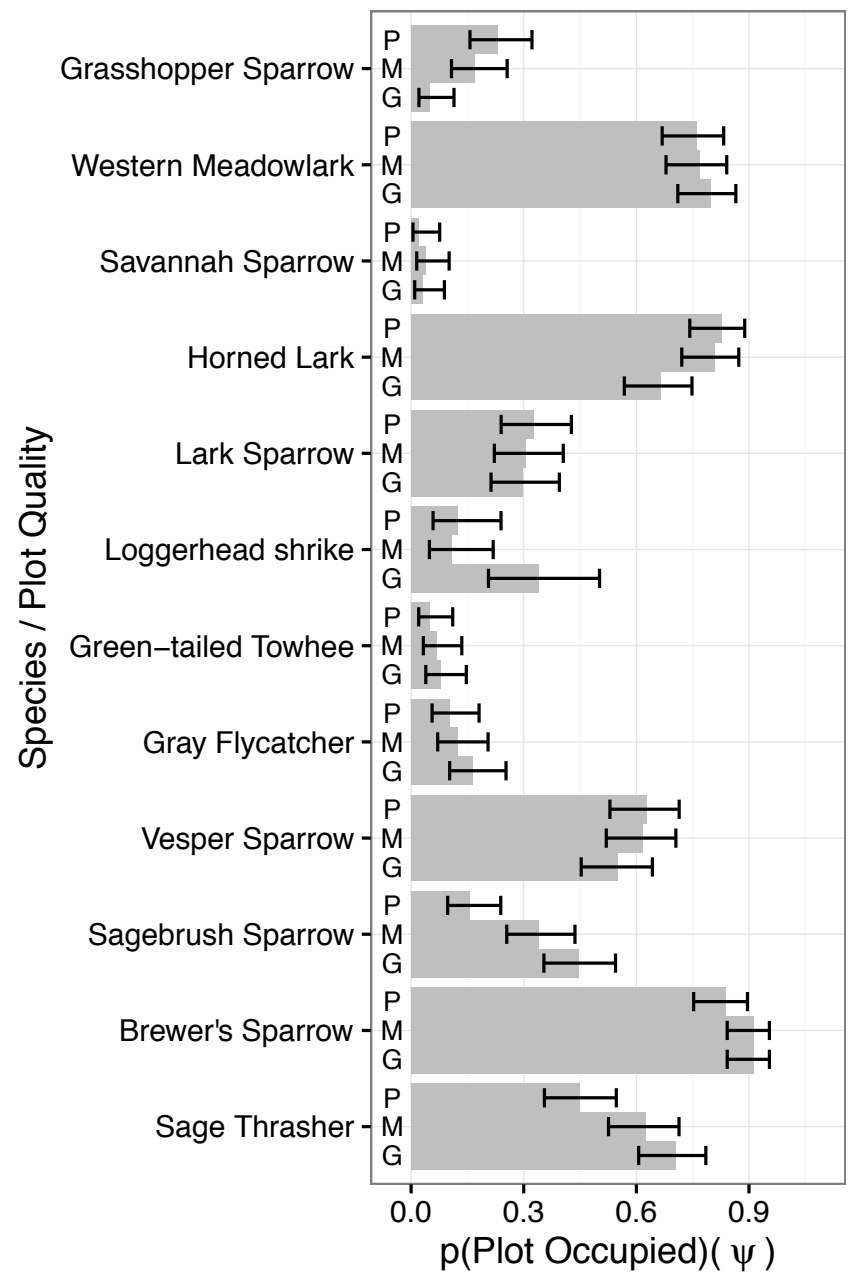

Figure 3. Probability of plot occupancy $(\Psi)$ by species and by subjective ranking of the plot's quality ( $G$, good; M, moderate; $P$, poor), shown with $95 \%$ confidence intervals.

\section{Bird-Habitat Relationships}

The number of models within two $\mathrm{AIC}_{c}$ units of the top model ranged from two for the Green-tailed Towhee to 13 for the Lark Sparrow (supplemental tables S1-S12 at www.westernfieldornithologists.org/48-1_tables.pdf). The Western Meadowlark was the only species for which the set of such models included all five principal components influencing the probability of presence at a point, given the plot is occupied ( $\Theta$; supplemental tables $S 1-S 12)$. For no species, however, did the top model include all five principal components 
Table 5 Directions of Effect of Parameters Appearing in the Top Model of Habitat Use for 12 Species of Birds Evaluated in the Shrub-Steppe of Idaho ${ }^{a}$

\begin{tabular}{|c|c|c|c|c|c|c|c|c|}
\hline \multirow[b]{2}{*}{ Species } & \multicolumn{5}{|c|}{ Point scale ${ }^{b}$} & \multicolumn{3}{|c|}{ Plot scale } \\
\hline & 1 & 2 & 3 & 4 & 5 & Elevation & Shrubland & Grassland \\
\hline Sage Thrasher & & - & & + & & + & + & \\
\hline Brewer's Sparrow & - & & + & + & + & + & + & \\
\hline Sagebrush Sparrow & & - & - & + & + & - & - & - \\
\hline Vesper Sparrow & & & + & & + & + & & - \\
\hline Gray Flycatcher & + & - & & & & + & + & \\
\hline Green-tailed Towhee & + & & & & & + & + & \\
\hline Loggerhead Shrike & + & & - & & - & - & - & \\
\hline Lark Sparrow & + & & - & & - & - & - & \\
\hline Horned Lark & - & & + & - & & - & + & + \\
\hline Savannah Sparrow & - & & + & & - & & + & - \\
\hline Western Meadowlark & + & + & & - & - & - & & + \\
\hline Grasshopper Sparrow & - & & & - & & - & - & \\
\hline
\end{tabular}

aSee supplemental tables S1-S12 at www.westernfieldornithologists.org/48-1_tables.pdf for selection of models by Akaike's information criterion.

${ }^{b}$ The five parameters are loadings resulting from principal component analysis of the 18 habitat variables; see Table 4 for definitions.

(Table 5). For all species, all three plot-scale habitat variables influencing the probability of plot occupancy $(\Psi)$ appeared in the set of models within two $\mathrm{AIC}_{c}$ units of the top model, but all three appeared in the top model for only the Sagebrush Sparrow and Horned Lark (Table 5).

Principal component 1, primarily representing increased shrub height (both sagebrush and other shrubs) and increased variability in shrub height (Table 4), was the principal component appearing in the greatest number of top models (nine; Table 5). Its direction of influence was mixed, with some species such as the Brewer's Sparrow and Gray Flycatcher preferring intermediate values (Table 5; Figure 4A). At least the Savannah Sparrow (Passerculus sandwichensis), however, appeared to be negatively associated with intermediate values (Figure 4B). Principal component 2, representing increased cover and height of invasive annual grasses (over 95\% cheatgrass, Bromus tectorum, in our area) and of annual forbs (Table 4), appeared in the top model for four species (Table 5). The influence was negative for the Gray Flycatcher, Sage Thrasher, and Sagebrush Sparrow, positive for the Western Meadowlark (Figures 5A and 5B). Principal component 3, primarily representing increased cover of perennial grasses and forbs (over 90\% of which were native species) and decreased bare ground (Table 4), appeared in the top model for seven species (Table 5). The direction of influence was mixed, but notably negative for the Sagebrush Sparrow and Loggerhead Shrike (Figures 6A and 6B).

Principal component 4 , primarily representing increased cover of sagebrush and total shrubs (Table 4), appeared in the top model for six species (Table 5). It had a strong positive relationship with all three sagebrush-obligate species (Figure 7A) and a negative relationship with species of open ground and grassland (Figure 7B). Principal component 5, representing increased 

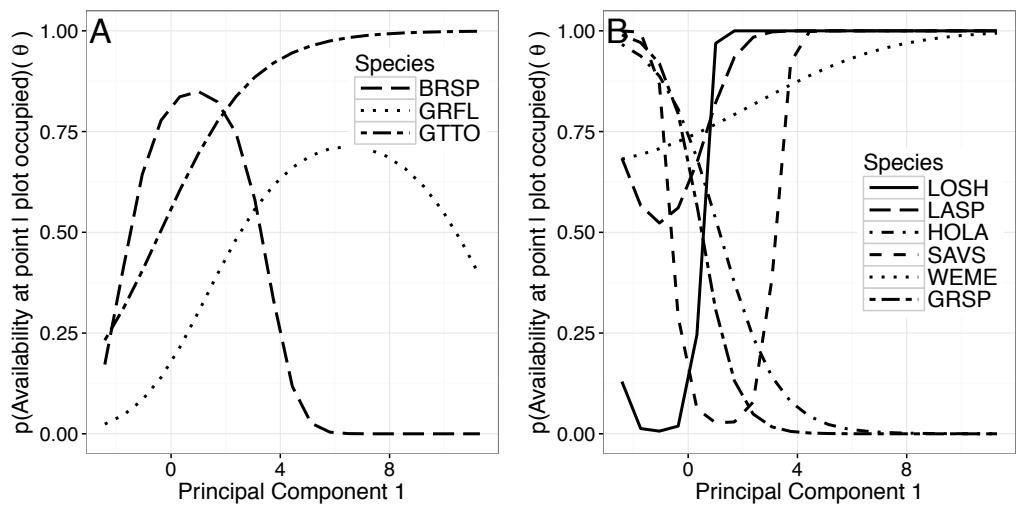

Figure 4. Probability of point occupancy given that the plot is occupied $(\Theta)$, generated from the top model for each species (see Table 3 for 4-letter alphabetic codes) across the range of values for principal component 1, representing a gradient of increasing height of shrubs (sagebrush and other species pooled) and increasing variability in this height. (A) Brewer's Sparrow, Gray Flycatcher, and Green-tailed Towhee, species more closely associated with sagebrush; (B) Loggerhead Shrike, Lark Sparrow, Horned Lark, Savannah Sparrow, Western Meadowlark, and Grasshopper Sparrow, not closely associated with sagebrush.

cover of shrubs other than sagebrush (Table 4), appeared in seven top models (Table 5). It had a positive effect on the sagebrush-obligate and near-obligate species (Figure 8A) and a negative or intermediate association with all others (Figure 8B).
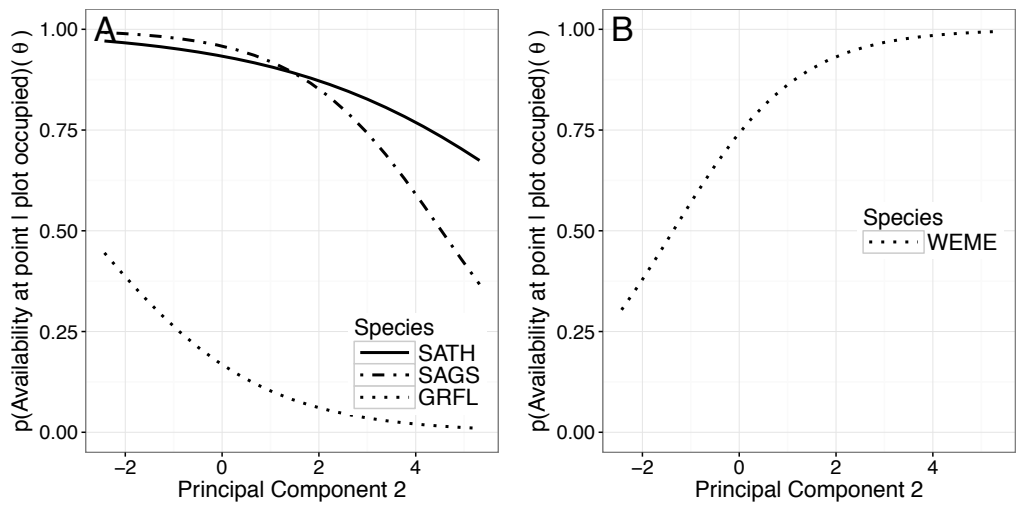

Figure 5. Probability of point occupancy given that the plot is occupied $(\Theta)$, generated from the top model for each species (see Table 3 for 4-letter alphabetic codes) across the range of values for principal component 2 , representing a gradient of increasing cover and height of annual grass (generally invasive). (A) The sagebrush-associated Sage Thrasher, Sagebrush Sparrow, and Gray Flycatcher; (B) the grassland-associated Western Meadowlark. 

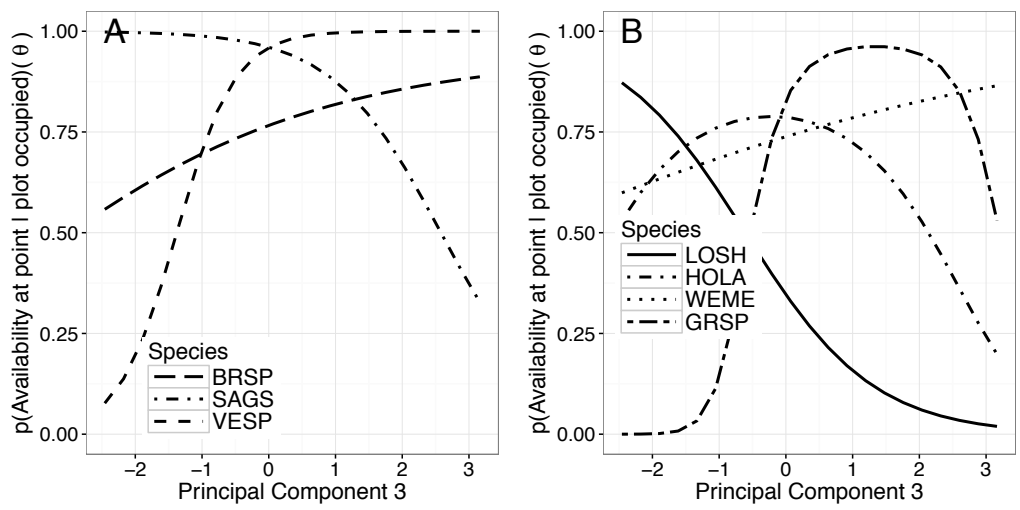

Figure 6. Probability of point occupancy given that the plot is occupied $(\Theta)$, generated from the top model for each species (see Table 3 for 4-letter alphabetic codes) across the range of values for principal component 3 , representing a gradient of increasing cover of perennial grass and forbs (consisting of over $90 \%$ native species). (A) The sagebrush-obligate Brewer's and Sagebrush Sparrows and "near-obligate" Vesper Sparrow; (B) Loggerhead Shrike, Horned Lark, Western Meadowlark, and Grasshopper Sparrow, species of more open habitats.

Of the variables influencing the probability of occupancy at the plot scale $(\Psi)$, mean elevation appeared in the top model for all species except the Savannah Sparrow (Table 5). For most species the association with elevation was nonlinear, the rate of occupancy peaking at intermediate elevations (Figures 9A and 9B). The proportion of the circle of radius $1 \mathrm{~km}$ with shrubs as the primary habitat appeared in the set of high-ranked models
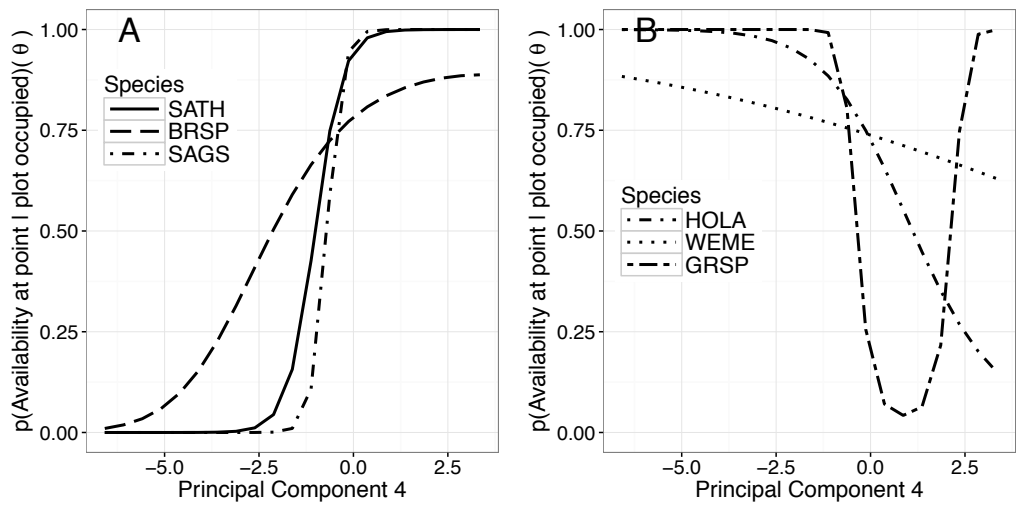

Figure 7. Probability of point occupancy given that the plot is occupied $(\Theta)$, generated from the top model for each species (see Table 3 for 4-letter alphabetic codes) across the range of values for principal component 4 , representing a gradient of increasing cover of both sagebrush and all shrubs combined. (A) The sagebrush-obligate Sage Thrasher, Brewer's Sparrow, and Sagebrush Sparrow; (B) Horned Lark, Western Meadowlark, and Grasshopper Sparrow, species of more open habitats. 

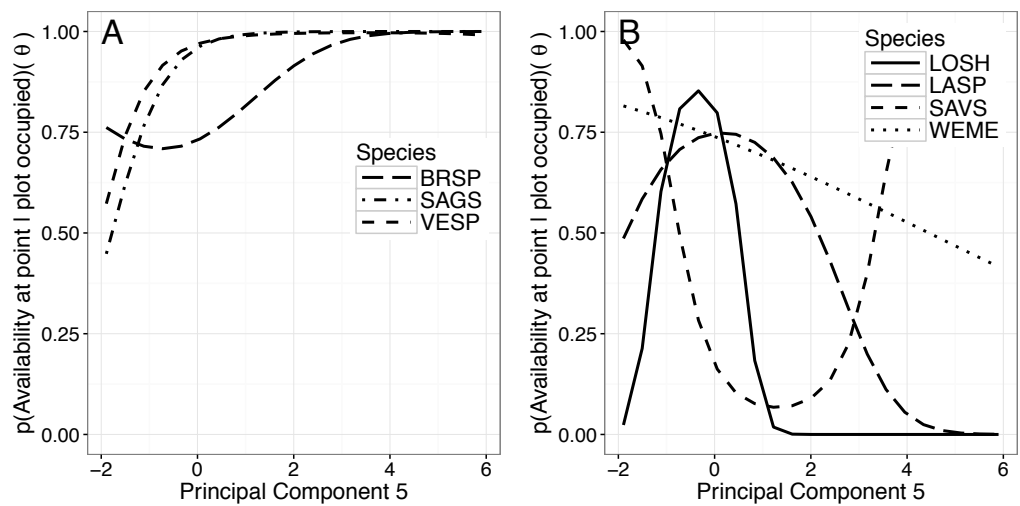

Figure 8. Probability of point occupancy given that the plot is occupied $(\Theta)$, generated from the top model for each species (see Table 3 for 4-letter alphabetic codes) across the range of values for principal component 5, representing a gradient of increasing cover of shrubs other than sagebrush. (A) The sagebrush-obligate Brewer's and Sagebrush Sparrows and "near-obligate" Vesper Sparrow; (B) Loggerhead Shrike, Lark Sparrow, Savannah Sparrow, and Western Meadowlark, species of more open habitats.

for all species except the Vesper Sparrow and Western Meadowlark (Table 5). The proportion of shrubs had a positive influence on the probability of plot occupancy $(\Psi)$ for all remaining sagebrush-obligate and sagebrushwoodland species, as well as the Horned Lark (Figures 10A and 10B). The
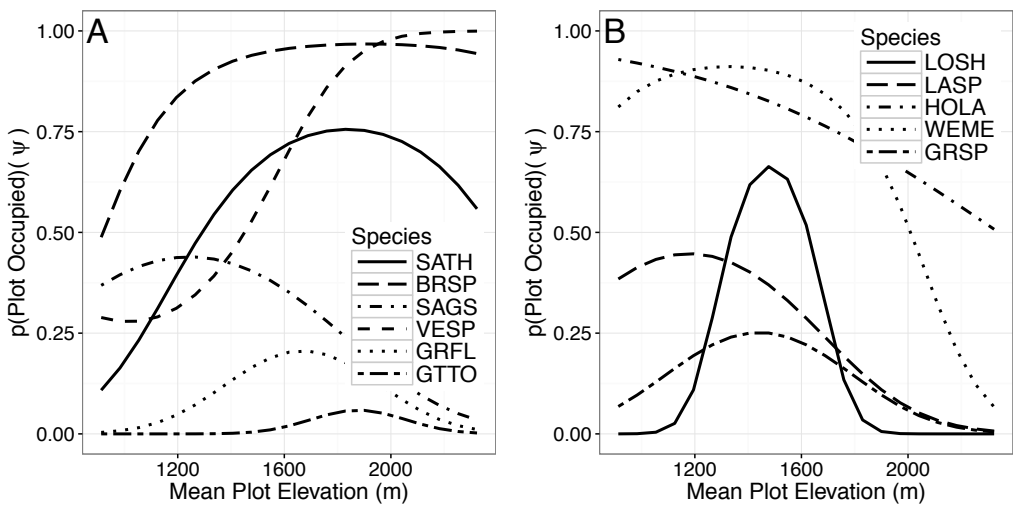

Figure 9. Probability of plot occupancy $(\Psi)$, generated from the top model for each species (see Table 3 for 4-letter alphabetic codes) across the range of values for mean elevation of the plot. (A) The sagebrush-obligate Sage Thrasher, Brewer's Sparrow, and Sagebrush Sparrow, "near-obligate" Vesper Sparrow, and sagebrush-woodland Gray Flycatcher and Green-tailed Towhee; (B) Loggerhead Shrike, Lark Sparrow, Horned Lark, Western Meadowlark, and Grasshopper Sparrow, species of more open habitats. 

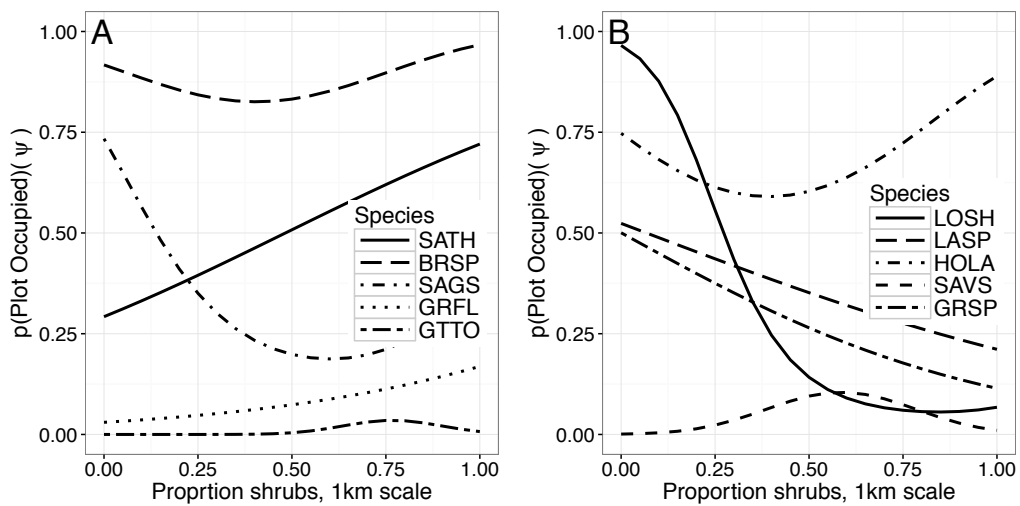

Figure 10. Probability of plot occupancy $(\Psi)$, generated from the top model for each species (see Table 3 for 4-letter alphabetic codes) across the range of values for the proportion of a 1-km circle centered in the plot of which shrubs are the primary habitat. (A) The sagebrush-obligate Sage Thrasher, Brewer's Sparrow, and Sagebrush Sparrow and shrub-associated Gray Flycatcher and Green-tailed Towhee; (B) Loggerhead Shrike, Lark Sparrow, Horned Lark, Savannah Sparrow, and Grasshopper Sparrow, species of more open habitats.

proportion of the circle with grassland as the primary habitat appeared in the top model for five species (Table 5). Its influence on occupancy by the Sagebrush Sparrow, Vesper Sparrow, and Savannah Sparrow was negative (Figures 11A and 11B).
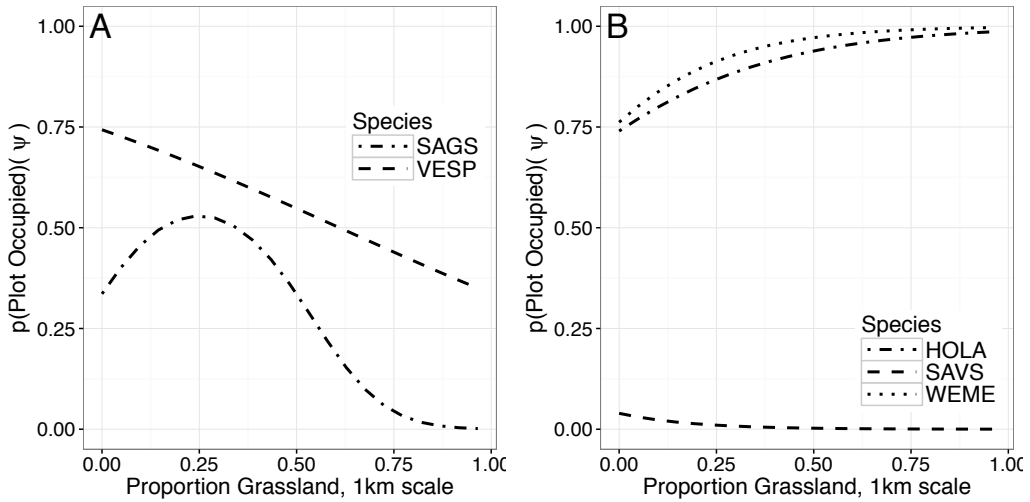

Figure 11. Probability of plot occupancy $(\Psi)$, generated from the top model for each species (see Table 3 for 4-letter alphabetic codes) across the range of values for the proportion of a $1-\mathrm{km}$ circle centered in the plot of which grassland is the primary habitat. (A) The sagebrush-obligate Sagebrush Sparrow and "near-obligate" Vesper Sparrow; (B) Horned Lark, Savannah Sparrow, and Western Meadowlark, typical of grassland. 


\section{DISCUSSION}

Our study of songbirds of sagebrush steppe differed from other studies in applying a consistent method across a larger area. Furthermore, our survey protocol helped ensure that we sampled a wide range of habitat quality within similar ecological sites, decreasing the confounding effects of differences at broader scales across our study area.

This study provided an independent evaluation of our subjective rating of local habitat quality. The three plots within each site were chosen subjectively by the degree to which native shrub habitat appeared to be intact. For the three sagebrush-obligate birds, occupancy rates of good and poor plots differed, but only for the Sagebrush Sparrow was the difference between good and moderate plots significant. Vander Haegen et al. (2000) also evaluated the same species against a more formal quantified index of habitat quality, also with three levels. Our failure to find much difference in songbird occupancy between plots rated good and moderate could be the result of a lack of calibration among the various biologists we asked to choose our plot locations, or it could point to the birds' lack of sensitivity to slight degradations of habitat, at least until some threshold is reached. Our finding a difference between plots rated good and moderate for the Sagebrush Sparrow reflects its high sensitivity to sagebrush cover (Wiens and Rotenberry 1981). Vander Haegen et al. (2000), however, did not corroborate this difference.

Two species, the Horned Lark and Grasshopper Sparrow, were more likely in plots designated as "poor," so a diversity in habitat quality (as defined by shrubs) within an ecological site may be leading to greater species diversity on a broad scale. However, any "advantage" of degradation of sagebrush steppe may be more than offset by the steep downward trends of the sagebrush-obligate species and the threat to this ecosystem in North America.

We found a high degree of similarity in habitat use of the sagebrushobligate species, but also some differences. The probability of a plot being occupied by the Sage Thrasher and Brewer's Sparrow was generally consistent: tending to be higher at higher elevations, with more shrub cover at the plot scale, and more sagebrush and more total shrubs at the point scale. The two differed in the Sage Thrasher dropping off at the highest elevation and reacting more negatively to invasive annual grasses at the point scale. Yet the proportion of grassland at the plot scale did not appear in the models for these two species. Similarly, Knick and Rotenberry (1995) found these two species' probability of occurrence to increase with shrub cover but was not significantly associated with increased grass cover. Furthermore, Hanser and Knick (2011) reported a positive association with shrub cover stronger than the negative influence of grass.

The Sagebrush Sparrow differed from the other two sagebrush obligates by its higher probability of occupancy at lower elevations and more negative association with grassland at the plot scale. Additionally, the proportion of shrubland at the plot scale generally had a negative association with Sagebrush Sparrow occupancy. This negative association at the plot scale was offset by a very strong positive association at the point scale with shrubs, both sagebrush and other species, suggesting that the Sagebrush Sparrow prefers 
a landscape more heterogeneous than does the Sage Thrasher or Brewer's Sparrow. Although their breeding ranges overlap spatially, the Sagebrush Sparrow breeds earlier than the Brewer's Sparrow. So elevation could be a factor more important to the Sagebrush Sparrow, or it may breed earlier because it occurs at lower elevations (Martin and Carlson 1998, Rotenberry et al. 1999). Within our study area, the various subspecies of sagebrush are often segregated by elevation (Meinke et al. 2009). If some species of birds favor certain subspecies of sagebrush, this segregation by elevation could explain some differences between the birds' responses.

At the point scale, all three sagebrush-obligate species were, as expected, positively associated with greater cover of sagebrush and two were associated with greater cover of total shrubs. The Brewer's Sparrow appeared in areas with shorter shrubs and less heterogeneity. The near-obligate Vesper Sparrow and sagebrush-woodland species were more diverse in their responses but were generally associated with characteristics of shrubs. For example, the Vesper Sparrow was associated with overall shrub cover instead of cover or height of sagebrush alone, and the Green-tailed Towhee responded most positively to shrub height but not to type of shrub. As expected, most species generally regarded as preferring open habitat responded negatively to characteristics of shrub cover at both the point and plot scales, although some, such as the Loggerhead Shrike, responded to positively to sparser shrub cover at the plot scale but to greater shrub height at the point scale.

At the plot scale we analyzed the effect of the proportion of area with grassland as the primary habitat. At the point scale we measured the effect of the presence of grass, regardless of whether the habitat was categorized as grassland or shrubland. At the point scale, both the Sage Thrasher and Sagebrush Sparrow responded negatively to increased cover of invasive annual grass. Management of cheatgrass may therefore be critical to conservation of these species. Both species feed on the ground, which may be easier in areas of bare ground or native bunchgrass areas than in areas covered in invasive annual grass (Martin and Carlson 1998, Reynolds et al. 1999). Furthermore, the Sagebrush Sparrow often nests low in shrubs, in native bunchgrasses, or even on the ground, all of which could be hampered by invasive annual grasses (Martin and Carlson 1998). Our models predict that the probability of a point being occupied by the Sagebrush Sparrow decreases as ground cover (invasive and native grasses and forbs) increases, supporting evidence for that species' association with bare ground. Thus some management intended to increase ground cover for sage-grouse may disfavor the Sagebrush Sparrow, as found also by Hanser and Knick (2011). By contrast, we found no response by the Brewer's Sparrow to coverage of annual grasses, suggesting that it may be able to tolerate invasive grasses as long as sagebrush remains.

The Vesper Sparrow showed no response to variation in shrub characteristics at the plot scale, and no response to variation in sagebrush cover at the point scale, but it was positively associated with increased cover of shrubs other than sagebrush at the point scale. Furthermore, it showed no response to invasive annual grasses but a strong positive affinity for perennial grasses and forbs (over 90\% native). These attributes are all consistent with other studies finding the Vesper Sparrow correlated with a sparse cover 
of shrubs of low to moderate height (Jones and Cornely 2002, Hanser and Knick 2011). Although the Vesper Sparrow has been classified as a "near-obligate" of sagebrush (Baker et al. 1976), our results do not support this close association, aligning more generally with sparse shrub cover, as expressed by Jones and Cornely (2002).

Among the mix of generalist and grassland species, correlations were, as expected, broad and inconsistent. Generally, the Horned Lark and Grasshopper Sparrow responded negatively to most attributes of shrubs at the point scale and positively to attributes of native ground cover. The Horned Lark was associated with higher proportions of shrub habitat at the plot scale, suggesting it may prefer habitat with widely dispersed shrubs and native ground cover. The other generalist species tended to respond positively to at least one attribute of shrubs.

A few limitations of our study design could have biased the results. The most significant was not integrating imperfect detection into the analysis. Accounting for imperfect detection has become the norm for these types of surveys, but was less prevalent at the time of our field work from 2002 to 2006. Nevertheless, many of our results agree with those of other studies. Two other aspects of the study could have affected the results: the surveys' broad range of dates (28 April-2 July) and broad range of times of day over which the surveys took place (within 5 hours of local sunrise). We expect that the probability of detection varied over these ranges, possibly biasing our results. However, other studies spanning such a range of geographies and elevational differences, such as Hanser and Knick (2011), have used similar spreads.

\section{Management Implications}

Sagebrush-steppe communities within the northern Great Basin and Intermountain West are projected to continue to lose ground as a result of climate change, altered fire regimes, spread of invasive species, and changes in human land use (Bradley 2010). In the nine years since the conclusion of this study, $28 \%$ of our plots have burned, and $18 \%$ of those have burned twice (Bureau of Land Management and Miller unpubl. data). This rate of fire far exceeds the past frequency for sagebrush, estimated at one fire every 137-342 years by Bukowski and Baker (2012). Our results suggest that further declines of sagebrush could result in further declines of sagebrush-obligate species but also that invasion of cheatgrass, even without reduction of sagebrush, can have a negative effect, as illustrated by the negative association of the Sage Thrasher and Sagebrush Sparrow with invasive annual grasses. We did not evaluate the effects of fragmentation of stands of sagebrush on the presence of these species, although a negative response to increased fragmentation has been demonstrated by Knick and Rotenberry (1995) and Vander Haegen et al. (2000).

While each of the three subjective habitat designations we evaluated was different from the perspective of composition, they did not represent different usage by two of three sagebrush-obligate birds. Only the Sagebrush Sparrow was encountered at a significantly different frequency in each of the three categories. This suggests that that managers should consider more careful designations, or simplify to two categories (poor and good). 
In conclusion, the sagebrush-obligate birds we evaluated were associated most closely with native stands of sagebrush and a mix of native ground cover and bare ground. Our broad geographic scope and deliberate selection of plots rated at different levels of quality have largely confirmed results of other studies (Wiens and Rotenberry 1981, Knick and Rotenberry 1995, Vander Haegen et al. 2000, Hanser and Knick 2011). Our analyses further highlight the niche separation and special requirements of three sagebrush-obligate species, such as the Sagebrush Sparrow's tending to occur at elevations lower than the Sage Thrasher and Brewer's Sparrow.

\section{ACKNOWLEDGMENTS}

We thank the U.S. Bureau of Land Management, the Idaho Department of Fish and Game, the Point Reyes Bird Observatory, the M. J. Murdock Charitable Trust, and individual donors for funding this project in 2002 and 2003. We thank the U. S. National Park Service for funding it in 2004 and the U. S. Bureau of Land Management and the National Fish and Wildlife Foundation for funding in 2006. We thank the National Fish and Wildlife Foundation and Boise State University's Intermountain Bird Observatory for funding the data analysis and reporting of this project. This work was supported in part by Institutional Development Awards (IDeA) from the National Institute of General Medical Sciences of the National Institutes of Health under grants P20GM103408 and P20GM109095, with additional acknowledgment of the National Science Foundation, grants 0619793 and 0923535, and the Idaho State Board of Education.

We thank Larry Barnes, Trent Brown, Eric Hallingstad, Adam Hannuksela, Mary Anne Hollenbeck, George Livingston, Chad Runco, and Doug Shepherd for joining the authors in completing the surveys in the field. Their dedication and work ethic, their knowledge of shrub-steppe ecology, the birds, the plants, and their resourcefulness made this project a huge success.

We thank Jason Sutter and Joe Bucher at U.S. Bureau of Land Management for assistance with selection of random sites by GIS, and Sean Finn, Great Northern Landscape Conservation Cooperative (previously with the U.S. Geological Survey), and Bonnie Claridge, U.S. Bureau of Land Management, for additional GIS assistance. We thank Steven E. Hanser for reviewing an earlier version of the manuscript and providing his valuable insight.

\section{LITERATURE CITED}

Abdi, H., and Williams, L. J. 2010. Principal component analysis. Wiley Interdisciplinary Reviews: Computational Statistics 2:433-459; doi 10.1002/wics.101.

Arnold, T. W. 2010. Uninformative parameters and model selection using Akaike's information criterion. J. Wildlife Mgmt. 74:1175-1178; doi 10.1111/j.19372817.2010.tb01236.x.

Baker, M. F., Eng, R. L., Gashwiler, J. S., Schroeder, M. H., and Braun, C. E. 1976. Conservation committee report on effects of alteration of sagebrush communities on the associated avifauna. Wilson Bull. 88:165-171.

Bradley, B. A. 2010. Assessing ecosystem threats from global and regional change: Hierarchical modeling of risk to sagebrush ecosystems from climate change, land use and invasive species in Nevada, USA. Ecography 33:198-208; doi 10.1111/j.1600-0587.2009.05684.x.

Brooks, M. L., D’Antonio, C. M., Richardson, D. M., Grace, J. B., Keeley, J. E., Ditomaso, J. M., Hobbs, R. J., Pellant, M., and Pyke, D. 2004. Effects of invasive alien plants on fire regimes. BioScience 54:677-688; doi 10.1641/0006-3568(2004)054[0677:EOIAPO]2.0.CO;2. 
Bukowski, B. E., and Baker, W. L. 2012. Historical fire regimes, reconstructed from land-survey data, led to complexity and fluctuation in sagebrush landscapes. Ecol. Appl. 23:546-564; 10.1890/12-0844.1.

Burnham, K., and Anderson, D. 2002. Model Selection and Multi-model Inference: A Practical Information-Theoretic Approach. Springer-Verlag, New York.

Chambers, J. C., and Wisdom, M. J. 2009. Priority research and management issues for the imperiled Great Basin of the western United States. Restor. Ecol. 17:707-714; doi 10.1111/j.1526-100X.2009.00588.x.

Connelly, J. W., Knick, S. T., Schroeder, M. A., and Stiver, S. J. 2004. Conservation assessment of Greater Sage-Grouse and sagebrush habitats. W. Assoc. Fish and Wildlife Agencies, Cheyenne, WY.

Dobbs, R. C., Martin, P. R., and Martin, T. E. 2012. Green-tailed Towhee (Pipilo chlorurus), in The Birds of North America Online (A. Poole, ed.), no. 368. Cornell Lab. Ornithol., Ithaca, NY; doi: 10.2173/bna.368.

Dobkin, D. S., and Sauder, J. D. 2004. Shrubsteppe landscapes in jeopardy: Distributions, abundances, and the uncertain future of birds and small mammals in the Intermountain West. High Desert Ecol. Res. Inst., Bend, OR.

Hanni, D. J., White, C. M., Van Lanen, N. J., Birek, J. J., Berven, J. M., and McLaren, M. A. 2013. Integrated monitoring of bird conservation regions (IMBCR): Field protocol for spatially balanced sampling of landbird populations. Rocky Mountain Bird Observatory, Brighton, CO.

Hanser, S. E., and Knick, S. T. 2011. Greater Sage-Grouse as an umbrella species for shrubland passerine birds. Studies in Avian Biol. 38:473-487.

Hanser, S. E., Knick, S. T., Hak, J., and Kagen, J. 2005. Distribution of sagebrush and associated vegetation in the Columbia Basin and Southwest regions. U.S. Geol. Surv. Forest and Rangeland Ecosystem Science Center, Snake River Field Station, Boise, ID.

Holmes, A. L., and Robinson, W. D. 2013. Fire mediated patterns of population densities in mountain big sagebrush bird communities. J. Wildlife Mgmt. 77:737-748; doi 10.1002/jwmg.540.

Jones, S. L., and Cornely, J. E. 2002. Vesper Sparrow (Pooecetes gramineus), in The Birds of North America (A. Poole and F Gill, eds.), no. 624. Birds N. Am., Philadelphia; doi 10.2173/bna.624.

Knick, S. T., and Rotenberry, J. T. 1995. Landscape characteristics of fragmented shrubsteppe habitats and breeding passerine birds. Cons. Biol. 9:1059-1071; doi 10.1046/j.1523-1739.1995.9051041.x-i1.

Knick, S. T., Rotenberry, J. T., and Leu, M. 2008. Habitat, topographical, and geographical components structuring shrubsteppe bird communities. Ecography 31:389-400; doi 10.1111/j.0906-7590.2008.05391.x.

Laake, J. 2014. RMark: R code for Mark analysis. R package version 2.1.9; http:// cran.r-project.org/web/packages/RMark/.

Leu, M., Hanser, S. E., and Knick, S. T. 2008. The human footprint in the West: A large-scale analysis of anthropogenic impacts. Ecol. Appl. 18:1119-1139; doi 10.1890/07-0480.1 10.1890/07-0480.1.

Martin, J. W., and Carlson, B. A. 1998. Sage Sparrow (Artemisiospiza belli), in The Birds of North America (A. Poole and F. Gill, eds.), no. 326. Birds N. Am., Philadelphia; doi 10.2173/bna.326.

McCarthy, M. A., Keith, D., Tietjen, J., Burgman, M. A., Maunder, M., Master, L., Brook, B. W., Mace, G., Possingham, H. P., Medellin, R., Andelman, S., Regan, H., Regan, T., and Ruckelshaus, M. 2004. Comparing predictions of extinction risk using models and subjective judgement. Acta Oecol. 26:67-74; doi 10.1016/j. actao.2004.01.008.

McCune, B., and Grace, J. B. 2002. Analysis of ecological communities. MjM Software Design, Gleneden Beach, OR. 
McElhinny, C., Gibbons, P., Brack, C., and Bauhus, J. 2005. Forest and woodland stand structural complexity: Its definition and measurement. Forest Ecol. Mgmt. 218:1-24; doi 10.1016/j.foreco.2005.08.034.

Meinke, C. W., Knick, S. T., and Pyvke, D. A. 2009. A spatial model to prioritize sagebrush landscapes in the Intermountain West (U.S.A.) for restoration. Restor. Ecol. 17:652-659; doi 10.1111/j.1526-100X.2008.00400.x.

Nichols, J. D., Bailey, L. L., O'Connell, A. F. Jr., Talancy, N. W., Grant, E. H. C., Gilbert, A. T., Annand, E. M., Husband, T. P., and Hines, J. E. 2008. Multi-scale occupancy estimation and modelling using multiple detection methods. J. Appl. Ecol. 45:1321-1329; doi 10.1111/j.1365-2664.2008.01509.x.

Paige, C., and Ritter, S. A. 1999. Birds in a sagebrush sea: Managing sagebrush habitats for bird communities. Partners in Flight Western Working Group, Boise, ID.

Pavlacky, D. C. Jr., Blakesley, J. A., White, G. C., Hanni, D. J., and Lukacs, P. M. 2012. Hierarchical multi-scale occupancy estimation for monitoring wildlife populations. Journal of Wildlife Management 76:154-162; doi 10.1002/jwmg.245.

Petersen, K. L., and Best, L. B. 1985. Brewer's Sparrow nest-site characteristics in a sagebrush community. J. Field Ornithol. 56:23-27.

Point Reyes Bird Observatory. 2001. Shrub-steppe Bird Project field protocol. PRBO, Stinson Beach, CA.

R Development Core Team. 2013. R: A language and environment for statistical computing. R Foundation for Statistical Computing, Vienna, Austria.

Reynolds, T. D. 1981. Nesting of the Sage Thrasher, Sage Sparrow, and Brewer's Sparrow in southeastern Idaho. Condor 83:61-64; doi 10.2307/1367605.

Reynolds, T. D., Rich, T. D., and Stephens, D. A. 1999. Sage Thrasher (Oreoscoptes montanus), in The Birds of North America (A. Poole and F. Gill, eds.), no. 463. Birds N. Am., Philadelphia; doi 10.2173/bna.463.

Rotenberry, J. T., Patten, M. A., and Preston, K. L. 1999. Brewer's Sparrow (Spizella breweri), in The Birds of North America (A. Poole and F. Gill, eds.), no. 390. Birds N. Am., Philadelphia; doi 10.2173/bna.390.

Schlaepfer, D. R., Lauenroth, W. K., and Bradford, J. B. 2012. Effects of ecohydrological variables on current and future ranges, local suitability patterns, and model accuracy in big sagebrush. Ecography 35:374-384; doi 10.1111/j.16000587.2011.06928.x.

U.S. Department of the Interior. 2000. A framework to assist in making sensitive species habitat assessments for BLM-administered public lands in Idaho. U.S. Dept. Interior, Boise, ID.

Vander Haegen, W. M., Dobler, F. C., and Pierce, D. J. 2000. Shrubsteppe bird response to habitat and landscape variables in eastern Washington, U.S.A. Cons. Biol. 14:1145-1160; 10.1046/j.1523-1739.2000.99293.x.

West, N. E. 2000. Synecology and disturbance regimes of sagebrush steppe ecosystems, in Proceedings: Sagebrush Steppe Ecosystems Symposium (P. G. Entwistle, A. M. DeBolt, J. H. Kaltenecker, and K. Steenhof, compilers), pp. 15-26. Publ. BLM/ID/PT-001001+1150, U.S. Bureau of Land Management, Boise, ID.

White, G. C., and Burnham, K. P. 1999. Program Mark: Survival estimation from populations of marked animals. Bird Study 46, Suppl.:120-138; doi 10.1080/00063659909477239.

Wiens, J. A., and Rotenberry, J. T. 1981. Habitat associations and community structure of birds in shrubsteppe environments. Ecol. Monog. 51:21-41; doi $10.2307 / 2937305$.

Wilson, S. K., Graham, N. A. J., and Polunin, N. V. C. 2007. Appraisal of visual assessments of habitat complexity and benthic composition on coral reefs. Mar. Biol. 151:1069-1076; doi 10.1007/s00227-006-0538-3. 